\title{
Recruitment of the parasitic pea crab Nepinnotheres novaezelandiae into green-lipped mussels Perna canaliculus
}

\author{
Oliver Trottier, Andrew G. Jeffs* \\ Leigh Marine Laboratory, Institute of Marine Science, University of Auckland, PO Box 349, Warkworth 0941, New Zealand
}

\begin{abstract}
Pea crab species are globally ubiquitous parasites of marine bivalves including several major aquaculture species. However, little is known about the environmental factors that affect their recruitment into aquacultured mussels. The effect of depth and distance from shore on the recruitment of the parasitic pea crab Nepinnotheres novaezelandiae into New Zealand greenlipped mussels Perna canaliculus was examined with a field experiment. The incidence of pea crab infection of mussels over 295 d was nearly double when deployed at 5-10 m depth (1.97\%) compared to $20-30 \mathrm{~m}$ depth $(0.96 \%)$, although it was not significantly different due to the overall low period prevalence in the experimental population. The sex ratio of crabs recovered was significantly skewed towards females with a ratio of $1: 14\left(\chi^{2}=11.3, \mathrm{p}<0.001\right)$. Infection with pea crabs was found to significantly reduce final mussel shell height on average by $28 \%(21.0 \mathrm{~mm})$ over $295 \mathrm{~d}$ (Mann-Whitney $U=6.0, \mathrm{p}<0.0001$ ). This study confirms that parasitism of greenlipped mussels by pea crabs has a significant impact on the growth of the mussels and suggests that the incidence of pea crabs will be higher in shallower water and when mussels are in closer proximity to the shore. With no control methods available for preventing pea crab infection, these results suggest that moving mussel farms offshore has the potential to reduce the incidence of pea crabs in mussels and warrants larger-scale assessment.
\end{abstract}

KEY WORDS: Larval settlement $\cdot$ Greenshell ${ }^{\mathrm{TM}} \cdot$ Parasite $\cdot$ Mussel farm $\cdot$ Aquaculture $\cdot$ Bivalve New Zealand

Resale or republication not permitted without written consent of the publisher

\section{INTRODUCTION}

Nepinnotheres novaezelandiae is the most common pea crab species in New Zealand, parasitizing a wide range of native shellfish in coastal waters (Hickman 1978, Palmer 1995). This species was originally known as Pinnotheres novaezelandiae until the transfer of the species to the genus Nepinnotheres (Ahyong \& Ng 2008). The most commercially important shellfish host of this species is the green-lipped mussel Perna canaliculus, in which the pea crab is found in 4 to $70 \%$ of individuals within wild populations (Jones 1977a, Hickman 1978, Baxter 1981, Bierbaum \& Ferson 1986, Palmer 1995, Miller et al. 2008).
The green-lipped mussel is an important aquaculture species in New Zealand, with annual production currently valued at over US\$200 million (New Zealand Ministry of Fisheries 2009, Aquaculture New Zealand 2014). The pea crab is a significant parasite for this mussel aquaculture industry, with a prevalence of $5.3 \%$ measured in an 18 mo old farmed mussel population, although prevalence of up to $25 \%$ has been anecdotally reported from mussel farms in other parts of the country (Trottier et al. 2012). Losses in farmed mussel production due to pea crabs are estimated to amount to US\$2.16 million annually in New Zealand. In addition, consumer complaints and the rejection of exports of shellfish by biosecurity 
authorities at international borders are likely to impose more severe financial consequences than the productivity losses due directly to parasitism (Trottier et al. 2012).

Despite the economic importance of $N$. novaezelandiae, only limited research has been available on the basic biology of the species (Jones 1977a,b, Wear \& Fielder 1985, McLay 1988, Stevens 1990). Recent efforts have provided a complete description of this species' larval development, and have measured the levels of parasite infection within mussel farms, their impact on mussel growth and the population structure and reproductive output of $N$. novaezelandiae (Trottier et al. 2012, Trottier \& Jeffs 2012, Fieckert 2013). This pea crab may also be an important primary host for the sporozoan parasite Nematopsis sp., which has a prevalence of around $80 \%$ in some wild populations of $P$. canaliculus (Jones 1975).

Despite the significant economic impact of these parasites, no practical methods of control have been identified to help the New Zealand mussel aquaculture industry lower the incidence of pea crabs in mussel farms. A previous study of the distribution of $N$. novaezelandiae within a single mussel farm found significantly lower numbers of pea crabs with increasing distance from the coast and the concomitant increase in depth beneath the suspended lines of cultured mussels (Trottier et al. 2012). The prevalence of pea crabs in mussels was on average nearly halved in mussels grown in $15 \mathrm{~m}$ of water depth at $140 \mathrm{~m}$ from the shoreline $(3.9 \%$ prevalence), versus those in $11 \mathrm{~m}$ of water depth at $50 \mathrm{~m}$ from the shoreline (6.8\% prevalence). Studies of natural benthic mussel populations have also implicated depth as a key factor in host selection and abundance among the pinnotherids, the family of crabs that are parasitic on shellfish (Houghton 1963, Pearce 1966, Seed 1969). For example, the optimal depth for the pea crab Fabia subquadrata in the northern horse mussel Modiolus modiolus is relatively shallow at 0 to $20 \mathrm{~m}$ (Pearce 1966). Having a mussel farm in close proximity to the shore would likely mean being close to neighbouring intertidal and benthic bivalve populations as well as the seafloor which may aid in increasing the incidence of pea crabs perhaps through the release of larval settlement cues from conspecifics or potential bivalve hosts. If recruitment of pea crabs to mussels is higher in shallower waters closer to the coast, then a potential solution that may help to reduce pea crab incidence in commercial mussel aquaculture operations could be to site mussel farms farther from shore and in deeper water. Therefore, the aim of this study was to experimentally test for higher incidence of $N$. novaezelandiae in green-lipped mussels closer to the coast and in shallower water to demonstrate that moving mussel farms farther offshore may help to reduce pea crab infection.

\section{MATERIALS AND METHODS}

\section{Experimental site and layout}

To investigate how distance from shore and depth together influence the recruitment of Nepinnotheres novaezelandiae into green-lipped mussels, experimental lines, each with 140 attached cultured juvenile mussels, were deployed along two $\sim 2 \mathrm{~km}$ long transects running perpendicular to the coast near Okakari Point on the northeastern coast of New Zealand (36 $15^{\prime} 35^{\prime \prime} \mathrm{S}, 174^{\circ} 46^{\prime} 6^{\prime \prime} \mathrm{E}$; (Fig. 1). The transects were parallel, placed $520 \mathrm{~m}$ apart and ran offshore from a natural intertidal population of green-lipped mussels known to contain pea crabs, indicating that the habitat was suitable for hosts and

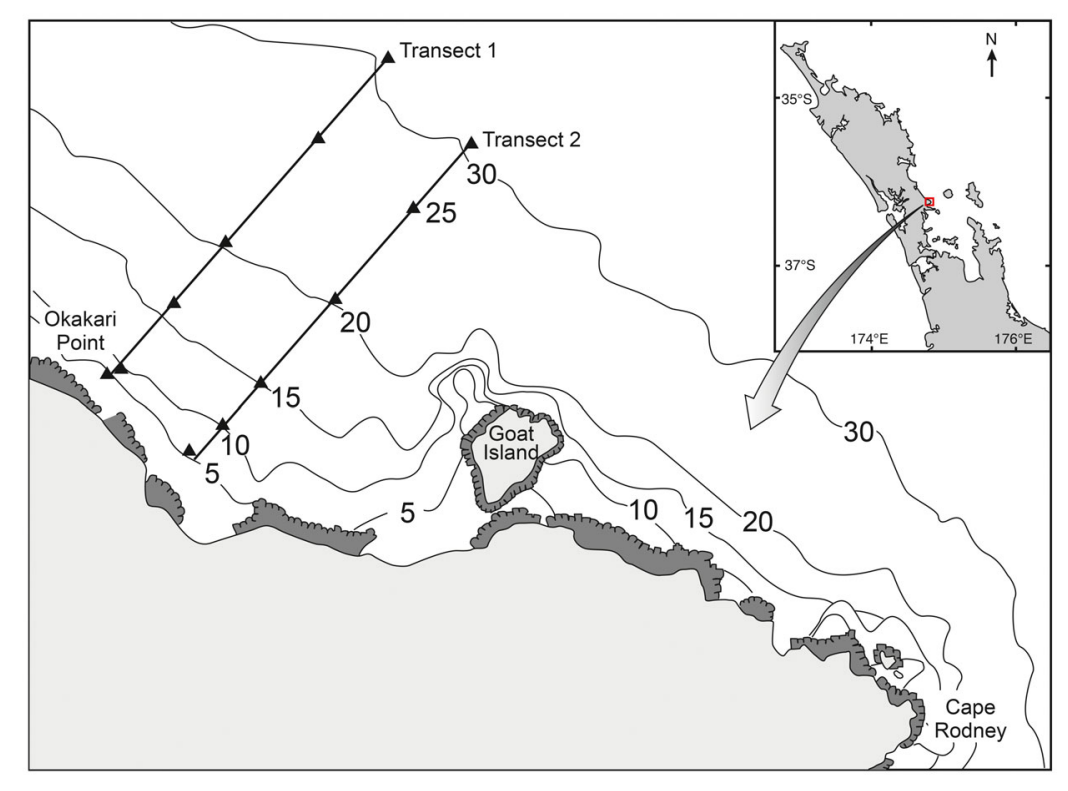

Fig. 1. Locations of 2 replicate transects running perpendicular to the coast between Okakari Point and Goat Island, on the northeastern coast of New Zealand's North Island. Each transect covered 6 positions at 5, 10, 15, 20, 25 and $30 \mathrm{~m}$ depth where a single line of experimental green-lipped mussels Perna canaliculus was deployed 
pea crabs. The coast in this region has a gradually sloping seafloor which allowed for a relatively consistent depth gradient with distance offshore for the 2 experimental transects.

\section{Source of juvenile mussels}

Live juvenile green-lipped mussels used on the experimental mussel lines were sourced from a commercial mussel facility at a size that is typical for seeding onto farms (around $30 \mathrm{~mm}$ in shell height; FAO 2005). Juveniles were placed inside mussel seeding socking, known as 'mussock' (Mussock International), through which $1 \mathrm{~m}$ of commercial dropper line was passed. The mussock served to hold the juvenile green-lipped mussels against the dropper line long enough for the mussels to attach to the mussel rope with byssus threads before the socking naturally biodegraded, which is the common practice used in green-lipped mussel farming (Jeffs et al. 1999, Alfaro et al. 2004, 2011, Carton et al. 2007). Once assembled, the 12 sections of mussel rope were suspended in an open top $10000 \mathrm{l}$ polypropylene water tank supplied with $20 \mathrm{l} \mathrm{min}^{-1}$ of continuously flowing raw sea water. Juvenile mussels were maintained suspended from the dropper line sections until required, and the tank was cleaned weekly.

\section{Removal of existing pea crabs}

Juvenile mussels used in this experiment needed to be free of any pea crabs that could have already settled into the mussels while previously at the commer-

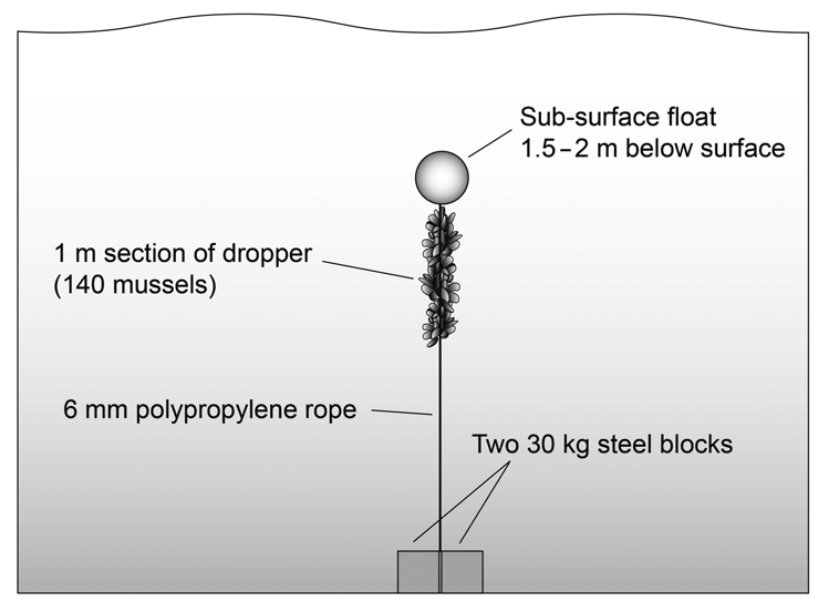

Fig. 2. Subsurface arrangement of the mooring of experimental lines of green-lipped mussels Perna canaliculus cial mussel facility. During a preliminary study, 2 known crustaceanacides, viz. pyrethrum and carbaryl, were experimentally tested to determine the minimum effective dose in order to remove any pea crabs from the mussels, whilst not unduly impacting the mussels themselves. Five green-lipped mussels known to contain pea crabs were placed in each of 7 polypropylene tanks (100 l capacity) with a raw sea water flow of $10 \mathrm{l} \mathrm{min}^{-1}$ and allowed to acclimate for $24 \mathrm{~h}$. Crustaceanacide treatment was then administered with a different dose for each tank, and the raw sea water flow was stopped temporarily for $60 \mathrm{~min}$ in complete darkness. After the dosing period, the raw sea water was then reinstated at $101 \mathrm{~min}^{-1}$, and both mussels and crabs were checked every $6 \mathrm{~h}$ for mortality for the following $5 \mathrm{~d}$. This experimental procedure was undertaken for pyrethrum at dosages of 0 (control), 0.0001, 0.001, 0.1, 10, 100 and $10000 \mu \mathrm{g}$ $\mathrm{I}^{-1}$ and for carbaryl at dosages of 0 (control), 0.075, $7.5,75,750,7500$ and $750000 \mu \mathrm{g} \mathrm{l}^{-1}$. The dosage experiments indicated which of the 2 crustaceanacides and what concentration provided a reliable means for killing all of the pea crabs in the mussels without collateral mortality of hosts. Consequently, this experimentally determined dosage was then used in the $10000 \mathrm{l}$ holding tank to treat the 12 experimental dropper lines of mussels to remove the pea crabs before the lines were placed in the field the following day.

\section{Experimental mussel lines}

Experimental mussel lines $(\mathrm{n}=12)$ were deployed at 6 locations along each transect at depths of approximately $5,10,15,20,25$ and $30 \mathrm{~m}$ (distances of about $300,460,700,1200,1740$ and $2120 \mathrm{~m}$, respectively, from the shore). Each line consisted of a $60 \mathrm{~kg}$ mooring block attached by a $6 \mathrm{~mm}$ polypropylene rope to a $10 \mathrm{l}$ subsurface buoy suspended approximately 1.5 to $2.0 \mathrm{~m}$ below mean low water springs (MLWS), with a single $1 \mathrm{~m}$ section of dropper line, enclosed in mussock and containing the juvenile green-lipped mussels (mean shell height $=30.3 \pm$ 0.49 [SE] $\mathrm{mm}, \mathrm{n}=140$ ), attached to the anchor line immediately below the buoy (Fig. 2), which is the typical arrangement for commercially farmed greenlipped mussels (Jeffs et al. 1999). Hence for every mooring site along each transect, the mussels remained in a position 2 to $3 \mathrm{~m}$ below the sea surface, whilst the water depth beneath the mussels varied (5, $10,15,20,25$ or $30 \mathrm{~m}$ ) depending on the position of the mooring along the transect line running offshore. 
Experimental lines were moored in position on 16 August 2012 and recovered by divers on 7 and 12 June 2013, after approximately 295 d. Upon recovery, the experimental mussel lines were immediately frozen and kept in storage for later processing, at which time all of the mussels that were recovered on the lines were shucked and the prevalence of pea crabs in each experimental group of mussels was recorded. Measurement of shell height was taken for all mussels containing pea crabs and for 20 randomly selected mussels without pea crabs from every experimental line. Carapace width of crabs was measured with a digital calliper to an accuracy of $0.01 \mathrm{~mm}$, and crab sex and stage were keyed according to Jones (1977b).

\section{Data analyses}

The effect of parasitism by pea crabs on shell height of mussels recovered from all of the mussel dropper lines compared to mussels without pea crabs was investigated with a Mann-Whitney $U$-test. A chisquared test was used to determine whether the sex ratio of recovered crabs varied from 1:1. A G-test of independence was performed to determine whether the incidence of pea crabs differed between the 2 transects and whether a relationship existed between depth/distance from shore and incidence of pea crabs. The effect of position of mussels along the transect (water depth and distance from shore) on resulting mussel shell height was investigated through the Kruskal-Wallis 1-way analysis of variance on pooled data from the 2 transects. Student's $t$-test was used on pairs of recovered experimental lines in order to identify any differences in shell height between the 2 transects.

\section{RESULTS}

\section{Crustaceanacide determination}

Of the 2 crustaceanacides tested (pyrethrum and carbaryl), both required relatively high doses to be completely effective against Nepinnotheres novaezelandiae compared with other common insecticides previously assessed with marine crustaceans (Cripe 1994). Pyrethrum required a minimum of $10000 \mathrm{~g} \mathrm{l}^{-1}$ in order to kill all pea crabs; however, this dose also proved to be lethal to $60 \%$ of the experimental mussels. At all dosage levels tested, the carbaryl was not lethal to the hosts whilst reliably killing all $N$. novaezelandiae from a concentration of $7500 \mu \mathrm{g} \mathrm{l}^{-1}$ and higher. Therefore, the lowest effective dose of carbaryl (i.e. $7500 \mu \mathrm{g} \mathrm{l^{-1 }}$ ) was used to kill all pea crabs in the 12 lines of mussels immediately before they were deployed in the field.

\section{Experimental line data}

Of the 12 experimental lines deployed on 16 August 2012, 3 were lost, probably during extreme weather events, which are common on this coast over this time of year. Green-lipped mussels on the recovered lines fared well, with a mean $\pm \mathrm{SE}$ of $108.4 \pm 3.7$ mussels recovered from the 140 initially seeded onto each experimental line. During the 295 d experiment, mussels without pea crabs had grown from $30.3 \pm 0.5 \mathrm{~mm}$ in shell height initially to an overall mean size of $74.6 \pm 0.3 \mathrm{~mm}$, with mean shell heights for individual experimental mussel lines ranging from $71.1 \pm 0.6$ to $79.5 \pm 1.4 \mathrm{~mm}$ (Table 1). Statistical analysis of mussel shell height data showed no difference in the shell height of mussels between the 2 transects when data for mussels without pea crabs was compared ( $p=0.36)$. Therefore, mussel shell height data for the 2 transects were combined for subsequent comparisons of shell height in relation to their position offshore. The position of mussels along the transects and increasing depth of deployment had a significant effect $(H=79.9, \mathrm{p}=0.001)$ on shell height, with mussels at greater depths, and therefore farther away from shore, being significantly larger than those found inshore at shallower depths. Calculation of the size of the effect on shell height due to position along the transects from the $\chi^{2}$ value showed that $41.2 \%$ of the variability in shell height was accounted for by water depth and distance from shore. Post hoc analysis revealed that all depths were significantly different from each other except for the comparison of 5 and $10 \mathrm{~m}$ depths, the 2 depths closest to the shore (Table 1).

The pea crabs found in the recovered mussels included 5 non-gravid females, 9 juvenile females and a single male with mean carapace widths of $7.5 \pm$ $0.1,5.9 \pm 0.2$ and $6.5 \mathrm{~mm}$, respectively. There was no difference in the mean carapace width of pea crabs recovered from experimental mussels at 5-15 m depth versus $20-30 \mathrm{~m}$ depth $(t=0.49, \mathrm{p}=0.62)$. No mussel contained more than 1 pea crab.

Parasitism by pea crabs had a deleterious effect on the growth of mussels, with the mean shell height of 
Table 1. Mean shell height $( \pm \mathrm{SE}$ ) of green-lipped mussels Perna canaliculus in relation to their position along 2 experimental replicate transects, as well as the presence or absence of the parasitic pea crab Nepinnotheres novaezelandiae. Incidence of pea crabs found at each position on the transects is also shown. nd: no data (mussel lines were lost); (-): not applicable

\begin{tabular}{|c|c|c|c|c|c|c|}
\hline \multirow{2}{*}{$\begin{array}{l}\text { Depth } \\
\text { (m) }\end{array}$} & \multirow{2}{*}{$\begin{array}{l}\text { Distance } \\
\text { from } \\
\text { shore }(\mathrm{m})\end{array}$} & \multirow{2}{*}{$\begin{array}{c}\text { Total } \\
\text { mussels }\end{array}$} & \multicolumn{2}{|c|}{ Mussel shell height (mm) } & \multicolumn{2}{|c|}{ Crabs -} \\
\hline & & & $\begin{array}{l}\text { Unpara- } \\
\text { sitized }\end{array}$ & Infected & $\begin{array}{c}\text { Total } \\
\text { no. }\end{array}$ & $\begin{array}{c}\text { Incidence } \\
(\%)\end{array}$ \\
\hline \multicolumn{7}{|c|}{ Transect 1} \\
\hline 5 & 300 & nd & nd & nd & nd & nd \\
\hline 10 & 460 & 115 & $71( \pm 0.6)$ & 55 & 1 & 0.9 \\
\hline 15 & 700 & 103 & $74( \pm 0.5)$ & $57( \pm 5.5)$ & 2 & 1.9 \\
\hline 20 & 1200 & 83 & $75( \pm 0.7)$ & 56 & 1 & 1.2 \\
\hline 25 & 1740 & 105 & $78( \pm 0.6)$ & - & 0 & 0.0 \\
\hline 30 & 2120 & 116 & $80( \pm 1.4)$ & 46 & 1 & 0.9 \\
\hline \multicolumn{7}{|c|}{ Transect 2} \\
\hline 5 & 300 & 111 & $71( \pm 0.8)$ & $52( \pm 5.0)$ & 3 & 2.7 \\
\hline 10 & 460 & 107 & $71( \pm 0.6)$ & $51( \pm 2.7)$ & 3 & 2.8 \\
\hline 15 & 700 & 121 & $75( \pm 0.5)$ & $57( \pm 4.5)$ & 2 & 1.7 \\
\hline 20 & 1200 & 115 & $77( \pm 0.6)$ & $56( \pm 9.0)$ & 2 & 1.7 \\
\hline 25 & 1740 & nd & nd & nd & nd & nd \\
\hline 30 & 2120 & nd & nd & nd & nd & nd \\
\hline
\end{tabular}

parasitized mussels $(53.6 \pm 1.7 \mathrm{~mm})$ being significantly smaller than that of unparasitized mussels at $74.6 \pm 0.3 \mathrm{~mm}(U=6.0, \mathrm{p}<0.0001)$. Mussels that were unparasitized grew an average of $44.0 \mathrm{~mm}$ or $0.2 \mathrm{~mm}$ $\mathrm{d}^{-1}$, while those that were parasitized grew $53 \%$ less, at $23.7 \mathrm{~mm}$ or $0.1 \mathrm{~mm} \mathrm{~d}^{-1}$ over the $295 \mathrm{~d}$ experimental period.

Mussels in transects 1 and 2 had a mean incidence of pea crabs of $1.33 \pm 0.30 \%$ and $2.07 \pm 0.37 \%$, respectively. A $G$-test of independence on the incidence of pea crabs in mussels between the 2 transects determined that there was no significant difference between the transects $(G=2.51, \mathrm{p}=0.11)$. This result allowed for the pooling of data from transects 1 and 2 to provide a larger data set for comparing the incidence of pea crabs in mussels among the 6 different depths, which was not significant $(G=4.67, \mathrm{p}=0.46, \mathrm{df}=5)$. However, there was a trend of decreasing incidence of pea crabs in mussels with increasing depth and distance offshore, with an incidence of pea crabs in $1.97 \%$ of all mussels at 5-15 m depth versus only $0.96 \%$ for all mussels deployed at 20-30 m depth. Post hoc statistical power analysis indicated that because of the overall small size of the incidence of pea crabs in the experimental mussels, we would need a sample size nearly 3 times larger than used in the current experiment (i.e. a total of 2500 mussels) in order to detect a difference between the 2 measured incidences of pea crabs in mussels at the different depth ranges with $80 \%$ confidence (Sokal \& Rohlf 1981).

\section{DISCUSSION}

The initial seeding of the 12 experimental mussel dropper lines in this study with 140 green-lipped mussels and subsequent recovery of an average of $108.4 \pm 3.7$ mussels after nearly 10 mo indicates that the environment chosen for experimentation was suitable for the mussels. Furthermore, the overall mean size of green-lipped mussels recovered was $74.6 \pm 0.3 \mathrm{~mm}$, which is typical for the size of cultured mussels of this age (Hickman 1979).

The overall incidence of pea crabs in the recovered experimental mussels was $1.5 \pm 0.30 \%$, and for some individual experimental lines, this value was as high as $2.8 \%$, especially those at 5 and $10 \mathrm{~m}$ water depth. These incidences are similar to what might be expected given that a previous examination of the prevalence of pea crabs within a nearby commercial mussel farm found that $5.3 \%$ of the 18 mo old mussels ( $\sim 40 \mathrm{~d}$ old) were parasitized (Trottier et al. 2012). These results indicate that pea crabs have the capacity to rapidly recruit into mussel populations, especially as all pea crabs recovered in this study were either late juveniles $(60 \%)$ or adults $(40 \%)$, which attests to the ready availability of larval settlers and their rapid development once larvae have settled (Jones 1977a). The initial juvenile instar stage after larval settlement in Nepinnotheres novaezelandiae has a carapace width of about $580 \mu \mathrm{m}$ (Fieckert 2013). Assuming that the largest pea crabs retrieved from the experimental lines had settled at this size 200 d prior to sampling, it would suggest that juvenile crabs grow rapidly about $0.04 \mathrm{~mm} \mathrm{~d}^{-1}$ in carapace width after the first instar.

The sex ratio of the crabs recovered from the experimental mussels was significantly skewed towards females, with a ratio of 1:14 $\left(\chi^{2}=11.3, \mathrm{p}<\right.$ 0.001). A strong bias towards females in adult pea crabs is common in populations of $N$. novaezelandiae (Jones 1977a, Trottier \& Jeffs 2012) as well as in related species, such as Pinnotheres sinensis (Sun et al. 2006), P. maculatus (72.8\%; Kruczynski 1974) and Arcotheres tivelae (9\%; Saeedi \& Ardalan 2010). Previous research from a commercial Perna canaliculus farm near the current study site found an even sex ratio for juveniles (54.7\% male: $45.3 \%$ female) and a similar bias toward females in adult crabs, which was 
thought to be due to higher mortality of mature male crabs (Leigh 1970, Trottier \& Jeffs 2012). It is possible that site-specific differences in predation of male crabs may cause differences in sex bias in N. novaezelandiae (Asama \& Yamaoka 2009).

Previous examination of the impact of pea crab parasitism within a commercial $P$. canaliculus farm in New Zealand found that host mussels suffered significant growth retardation as a result of the parasite, which ultimately resulted in substantial production losses for individual mussel farms, and across the New Zealand mussel aquaculture industry, i.e. US\$2.16 million annually (Trottier et al. 2012). On average, the wet weight of mussels was found to be reduced by $30 \%$ and shell height by $13.5 \%$ (10.9 mm) in parasitized versus non-parasitized mussels cultured on the farm for 18 mo (Trottier et al. 2012). In the current study, parasitism of mussels with pea crabs was found to significantly reduce mussel shell height on average by $24 \%$ (21.0 mm) over $295 \mathrm{~d}$ in conditions equivalent to a culture situation. The more pronounced impact of the parasite on mussels in this current study may be due to the younger age of the mussels or localised differences in the growing conditions.

In a previous study, the prevalence of pea crabs was found to vary significantly across a mussel farm, with more pea crabs (6.8\%) present in mussels held on droppers in shallow water $(11 \mathrm{~m})$ located $50 \mathrm{~m}$ from shore compared to those on droppers suspended in deeper water $(15 \mathrm{~m})$ and $160 \mathrm{~m}$ from shore (3.9\%; Trottier et al. 2012). While not significantly different, there was a trend of a similar magnitude in the current study, with the incidence of pea crabs in mussels nearly halving with increasing depth and distance offshore, i.e. after $295 \mathrm{~d}, 1.97 \%$ of mussels were parasitized at 5-10 m depth and 300-460 m distance offshore, versus only $0.96 \%$ for mussels at 20-30 m depth and 1740-2120 m distance offshore. Therefore, the results of this current experimental study support the proposition that the incidence of pea crab parasitism will be lower in mussels located farther offshore in deeper water. While a commercial mussel farm is different in structure from a natural intertidal mussel bed, in wild mussel populations environmental factors such as intertidal height and water depth of the mussels, can greatly influence the incidence of parasites (Houghton 1963, Pearce 1966, Seed 1969, Kruczynski 1974). For example, in many other species of pea crabs such as P. maculatus, Fabia subquadrata and $P$. pisum, the position of hosts either in the intertidal zone or benthic community strongly influences the resulting prevalence of the parasites in the population of wild shellfish (Houghton 1963, Kruczynski 1974, Anderson 1975). The reason for this variation in the incidence of pea crabs in mussels growing on ropes, as occurs in mussel farms, is not clear, but may be related to larval settlement cues associated with shallower waters (Stevens 1990). Crustacean larvae accelerated metamorphosis when appropriate settlement cues are present, such as chemical odours from conspecifics and substratum, and acoustic cues, all of which may be in higher concentration and intensity closer to the intertidal zone where green-lipped mussels are most abundant naturally (Gebauer et al. 2003, Stanley et al. 2010, Pine et al. 2012).

\section{CONCLUSIONS}

This study reconfirms that parasitism of Perna canaliculus by Nepinnotheres novaezelandiae has a significant impact on the growth of the mussels (Trottier et al. 2012). The results indicate that the incidence of $N$. novaezelandiae in mussels tends to be higher in shallower water and in closer proximity to the shore, as has previously been observed with significant differences in abundance across a largescale commercial mussel farm extending out from the coast (Trottier et al. 2012). The result suggests that moving mussel farms farther offshore has the potential to reduce the incidence of pea crabs in the cultured mussels by around half (Trottier et al. 2012). It would also appear that greater depth and distance from shore can also help to increase the growth rate of green-lipped mussels and assist in overall productivity for the mussel farming operation.

Acknowledgements. This research was supported by the University of Auckland Doctoral Scholarship Fund and the Glenn Family Foundation. We are very grateful to Peter Vitasovich of Greenshell New Zealand Ltd for supplying the juvenile mussels for this research. Many thanks to the crew of the RV 'Hawere' for help with seeding and recovery of the mussels used in this research. This work was conducted under University of Auckland Animal Ethics Committee approval number R864.

\section{LITERATURE CITED}

Ahyong ST, Ng RKL (2008) Alain raymondi, a new species of deepwater pinnotherid crab (Crustacea: Decapoda: Brachyura) from the Philippines, commensal with holothurians. Zootaxa 1919:61-68

Alfaro AC, Jeffs AG, Creese RG (2004) Bottom-drifting algal/ mussel spat associations along a sandy coastal region in northern New Zealand. Aquaculture 241:269-290 
Alfaro AC, Jeffs AG, Gardner JPA, Bollard Breen BA, Wilkin J (2011) Green-lipped mussels in GLM 9. The New Zealand Ministry of Fisheries, Wellington

Anderson GL (1975) The effects of intertidal height and the parasitic crustacean Fabia subquadrata Dana on the nutrition and reproductive capacity of the California sea mussel Mytilus californianus Conrad. Veliger 17: 299-306

Aquaculture New Zealand (2014) Overview of New Zealand aquaculture industry. Available at www.aquaculture. org.nz/industry/overview/ (accessed 26 Nov 2014)

Asama H, Yamaoka K (2009) Life history of the pea crab, Pinnotheres sinensis, in terms of infestation in the bivalve mollusc, Septifer virgatus. Mar Biodivers Rec 2:e77

Baxter AS (1981) Ecology of the New Zealand pea crab, Pinnotheres novaezelandiae Filhol, 1886 (Brachyura: Pinnotheridae). BSc Honors thesis, University of Canterbury

Bierbaum RM, Ferson S (1986) Do symbiotic pea crabs decrease growth rate in mussels? Biol Bull (Woods Hole) 170:51-61

Carton AG, Jeffs AG, Foote G, Palmer H, Bilton J (2007) Evaluation of methods for assessing the retention of seed mussels (Perna canaliculus) prior to seeding for growout. Aquaculture 262:521-527

Cripe GM (1994) Comparative acute toxicities of several pesticides and metals to Mysidopsis bahia and postlarval Penaeus duorarum. Environ Toxicol Chem 13:1867-1872

FAO (Food and Agriculture Organization of the United Nations) (2005) Cultured aquatic species information programme. FAO, Rome. Available at www.fao.org/fishery/ culturedspecies/Perna_canaliculus/en (accessed 8 Sep 2013)

Fieckert J (2013) Embryonic development, larval development and larval settlement of the New Zealand pea crab, Nepinnotheres novaezelandiae (Filhol 1885). MSc thesis, University of Auckland

> Gebauer P, Paschke K, Anger K (2003) Delayed metamorphosis in decapod crustaceans: evidence and consequences. Rev Chil Hist Nat 76:169-175

- Hickman RW (1978) Incidence of a pea crab and a trematode in cultivated and natural green-lipped mussels. NZ J Mar Freshw Res 12:211-215

Hickman RW (1979) Allometry and growth of the greenlipped mussel Perna canaliculus in New Zealand. Mar Biol 51:311-327

Houghton D (1963) The relationship between tidal level and occurrence of Pinnotheres pisum in Mytilus edulis. $\mathrm{J}$ Anim Ecol 32:253-257

Jeffs AG, Holland RC, Hooker SH, Hayden BJ (1999) Overview and bibliography of research on the Greenshell ${ }^{\mathrm{TM}}$ mussel, Perna canaliculus, from New Zealand waters. J Shellfish Res 2:347-360

Jones JB (1975) Nematopsis n. sp. (Sporozoa: Gregarinia) in Perna canaliculus. NZ J Mar Freshw Res 9:567-568

Jones JB (1977a) Natural history of the pea crab in Wellington Harbour, New Zealand. NZ J Mar Freshw Res 11: $667-676$

Editorial responsibility: Stephen Feist,

Weymouth, UK
Jones JB (1977b) Post-planktonic stages of Pinnotheres novaezelandiae Filhol, 1886 (Brachyura: Pinnotheridae). NZ J Mar Freshw Res 11:145-158

Kruczynski WL (1974) Relationship between depth and occurrence of pea crabs, Pinnotheres maculatus, in blue mussels, Mytilus edulis, in the vicinity of Woods Hole, Massachusetts. Chesapeake Sci 15:167-169

> Leigh EG Jr (1970) Sex ratio and differential mortality between the sexes. Am Nat 104:205-210

McLay CL (1988) Brachyura and crab-like Anomura of New Zealand. Leigh Lab Bull 22:1-463

- Miller A, Inglis GJ, Poulin R (2008) Use of the introduced bivalve, Musculista senhousia, by generalist parasites of native New Zealand bivalves. NZ J Mar Freshw Res 42: 143-151

New Zealand Ministry of Fisheries (2009) Greenshell mussels. Available at www.fish.govt.nz/en-nz/Commercial/ Aquaculture/default.htm (accessed 3 Nov 2012)

Palmer P (1995) Occurrence of a New Zealand pea crab, Pinnotheres novaezelandiae, in five species of surf clam. Mar Freshw Res 46:1071-1075

Pearce JB (1966) The biology of the mussel crab, Fabia subquadrata, from the waters of San Juan Archipelago, Washington. Pac Sci 20:3-35

> Pine MK, Jeffs AG, Radford CA (2012) Turbine sound may influence the metamorphosis behaviour of estuarine crab megalopae. PLoS ONE 7:e51790

> Saeedi S, Ardalan AA (2010) Incidence and biology of ArCotheres tivelae (Crustacea: Decapoda) in Amiantis umbonella (Bivalvia: Veneridae) on the northern coast of the Persian Gulf, Iran. J Mar Biol Assoc UK 90:655-661

Seed R (1969) The incidence of the pea crab Pinnotheres pisum in two types of Mytilus (Mollusca: Bivalvia) from Padstow, south-west England. J Zool 158:413-420

Sokal RR, Rohlf FJ (1981) Biometry, 2nd edn. Freeman, San Francisco, CA

> Stanley JA, Radford CA, Jeffs AG (2010) Induction of settlement in crab megalopae by ambient underwater reef sound. Behav Ecol 21:113-120

> Stevens PM (1990) Specificity of host recognition of individuals from different host race of symbiotic pea crabs (Decapoda: Pinnotheridae). J Exp Mar Biol Ecol 143: 193-207

Sun W, Sun S, Yuqi Y, Baowen Y, Weibo S (2006) The prevalence of the pea crab, Pinnotheres sinensis, and its impact on the condition of the cultured mussel, Mytilus galloprovincialis, in Jiaonan waters (Shandong Province, China). Aquaculture 253:57-63

Trottier O, Jeffs AG (2012) Biological characteristics of parasitic Nepinnotheres novaezelandiae within a Perna canaliculus farm. Dis Aquat Org 101:61-68

Trottier O, Walker D, Jeffs AG (2012) Impact of the parasitic pea crab Pinnotheres novaezelandiae on aquacultured New Zealand green-lipped mussels, Perna canaliculus. Aquaculture 344-349:23-28

Wear RG, Fielder DR (1985) The marine fauna of New Zealand: larvae of the Brachyura (Crustacea, Decapoda). NZOI Mem 92:1-90

Submitted: June 27, 2014; Accepted: September 24, 2014 Proofs received from author(s): November 26, 2014 